medRxiv preprint doi: https://doi.org/10.1101/2022.01.03.22268699; this version posted January 5, 2022. The copyright holder for this preprint (which was not certified by peer review) is the author/funder, who has granted medRxiv a license to display the preprint in perpetuity.
It is made available under a CC-BY 4.0 International license.

\title{
Effect of vitamin D on infection and inflammation in patients with cystic fibrosis: a systematic review and meta-analysis
}

Nelufa Begum PhD ${ }^{1}$

Abdullah Al Tarique $\mathrm{PhD}^{1}$

Tamara Blake $\mathrm{PhD}^{1}$

Dwan Vilcins $\mathrm{PhD}^{1}$

Mohammad Zahirul Islam $\mathrm{PhD}^{1}$

Nazrul Islam $\mathrm{PhD}^{2}$

Robert S Ware $\mathrm{PhD}^{3}$

Peter Sly MBBS, MD, DSc, FRACP, FAHMS, FERS, FThorSoc, FAPSR, ATSF ${ }^{1}$

${ }^{1}$ Children's Health and Environment Program, Child Health Research Centre, The University of Queensland, South Brisbane, Qld 4101, Australia

${ }^{2}$ Faculty of Health, Queensland University of Technology, Qld 4000, Australia

${ }^{3}$ Menzies Health Institute Queensland, Griffith University, Nathan, Qld 4111, Australia

Corresponding Author:

Dr Nelufa Begum, Children's Health and Environment Program, Child Health Research Centre, 62 Graham St, South Brisbane 4101, Qld, Australia

Ph: +61 730697382

Email: n.begum@uq.edu.au 
medRxiv preprint doi: https://doi.org/10.1101/2022.01.03.22268699; this version posted January 5, 2022. The copyright holder for this preprint (which was not certified by peer review) is the author/funder, who has granted medRxiv a license to display the preprint in perpetuity.
It is made available under a CC-BY 4.0 International license.

\begin{abstract}
Background

Cystic fibrosis (CF) is a genetic disorder in which the respiratory system gets clogged with mucus leads to progressive lung damage. There is no known cure for CF but several treatments to manage symptoms and reduce complications. Vitamin D deficiency is common in $\mathrm{CF}$ associated with increased infection and inflammation. This systematic review and metaanalysis will evaluate the effectiveness of vitamin D treatment in reducing respiratory tract infection and inflammation in patients with CF.
\end{abstract}

\title{
Methods
}

Randomized and quasi-randomised studies in $\mathrm{CF}$ patients with control groups will be identified. The antibacterial activity of vitamin D supplementation will help in reducing respiratory tract infection and inflammation in CF. Overall effects of vitamin D in terms of infection and inflammatory markers such as C-reactive protein, inflammatory cytokine interleukin (IL)-6, IL-8, IL-17, IL-23, antimicrobial peptide (LL-37), lung function defined by forced expiratory volume in 1 second $\left(\mathrm{FEV}_{1}\right) \%$, other assessed respiratory parameters will be calculated using random-effect models. Study quality will be assessed using RoB 2 - A revised Cochrane Risk of Bias tool for randomised trials. The overall quality of evidence for each outcome will be summarised according to the Grading of Recommendations Assessment, Development, and Evaluations (GRADE) framework. 


\section{BACKGROUND}

Cystic fibrosis (CF) is a common inherited respiratory disease (1). There is great geographic and ethnic variation in the prevalence of this respiratory disease, but CF has the highest prevalence in Europe, North America, and Australia and remains mainly a disease in Caucasians (2). Patients with CF are more vulnerable to chronic respiratory infection and inflammation in the lower airways, which lead to progressive lung damage. Most patients with $\mathrm{CF}$ have reduced capacity to combat chronic respiratory infection, and inflammation leading to respiratory failure is the most common cause of morbidity and mortality in individuals with CF. Although CF cannot be cured, there are several treatment options available to manage symptoms and reduce complications.

Vitamin D deficiency is common in children and adults with CF. Vitamin D is associated with inflammatory response in respiratory tract infections (3-5). Some studies have reported that more than $90 \%$ of CF patients have vitamin D deficiency $(6,7)$, and the correction of vitamin D deficiency reduces inflammation and decreases infection in patients with CF. Vitamin D is a fat-soluble vitamin that is poorly absorbed by individuals with CF unless pancreatic enzyme therapy is adequate. Vitamin D levels are measured routinely at CF annual review, and vitamin supplementation is routine in $\mathrm{CF}$ management. To prevent pancreatic insufficiency and deficiency of fat-soluble vitamin $\mathrm{D}$, patients with $\mathrm{CF}$ receive age-group-specific vitamin $\mathrm{D}$ supplementation according to international CF nutritional guidelines (8). It is well-known that with ongoing supplementation, vitamin D levels improve with pancreatic enzymes (9). A study demonstrated that vitamin $\mathrm{D}$ deficiency is associated with alterations in microbiota composition that promote inflammation and supplementation with vitamin $\mathrm{D}$ has the potential to impact microbiota composition. It reports that airway microbiota in $\mathrm{CF}$ is disrupted by chronic inflammation in the respiratory, and recurrent lung infection (2). Vitamin D deficiency increases susceptibility to infectious diseases and affects control of the inflammation process. Thus, vitamin D supplementation aims to increase vitamin D levels with potential long-term beneficial effects, including antibacterial activity on pulmonary function in patients with $\mathrm{CF}$.

It is well-established that vitamin D deficiency is associated with increased inflammation. Vitamin D has been reported to have an antibacterial effect to reduces respiratory tract infection and inflammation in CF. A study has reported increased vitamin D suppresses the production of proinflammatory cytokines interleukin (IL)-6 and IL-8 and increase the production of the antimicrobial peptide (AMP) and LL-37 from CF respiratory epithelial cells. It indicated that vitamin D was evaluated for its potential to increase LL-37 and reduce inflammation (10). 
medRxiv preprint doi: https://doi.org/10.1101/2022.01.03.22268699; this version posted January 5, 2022. The copyright holder for this preprint (which was not certified by peer review) is the author/funder, who has granted medRxiv a license to display the preprint in perpetuity.
It is made available under a CC-BY 4.0 International license.

Vitamin D treatment decreases plasma IL-8 concentration, decreases neutrophil count, reduces inflammation, and improves lung function defined by forced expiratory volume in 1 second $\left(\mathrm{FEV}_{1}\right) \%$ predicted. The study indicated that a high dose of vitamin D improved vitamin D status, which leads a better respiratory function (11). A recent study demonstrated that the antiinflammatory effect of vitamin D reduced the level of IL-17A and IL-23 in the airway of CF patients with chronic Pseudomonas aeruginosa infection and contributed to the exaggerated inflammatory response to pulmonary infection (12).

This review aims to explore whether, in patients with $\mathrm{CF}$, supplementation with vitamin $\mathrm{D}$ compared with placebo, is effective in reducing respiratory tract infection and inflammation. Additionally, this review will help identify the relationship between vitamin D status in CF and lung function outcomes.

This review protocol will follow the guidelines for the Preferred Reporting Items for Systematic Reviews and Metanalysis (PRISMA) (13) and is reported here using the Guidance notes for registering a systematic review protocol with PROSPERO provided by the Centre for Reviews and Dissemination (14).

\section{PROSPERO ITEMS}

\section{Review title}

Effect of vitamin D on infection and inflammation in patients with cystic fibrosis: a systematic review and meta-analysis

\section{Original language title}

As above

\section{Anticipated or actual start date}

7 January 2022

\section{Anticipated completion date}

7 July 2022

\section{Stage of review at time of this submission}

Preliminary searches and piloting of the study selection process are underway. After submitting this protocol, the search will be re-run, and eligible journal articles will be identified for inclusion in meta-analyses.

\section{Named contact}


medRxiv preprint doi: https://doi.org/10.1101/2022.01.03.22268699; this version posted January 5, 2022. The copyright holder for this preprint (which was not certified by peer review) is the author/funder, who has granted medRxiv a license to display the preprint in perpetuity.
It is made available under a CC-BY 4.0 International license.

Dr Nelufa Begum

\section{Named contact email}

n.begum@uq.edu.au; Dr Nelufa Begum - Child Health Research Centre, The University of Queensland (uq.edu.au)

\section{Named contact address}

Child Health Research Centre, 62 Graham St, South Brisbane 4101, Qld, Australia

\section{Named contact phone number}

+61730697382

\section{Organisational affiliation of the review}

Children's Health and Environment Program, Child Health Research Centre, The University of Queensland

\section{Review team members and their organisational affiliations:}

Nelufa Begum, Children's Health and Environment Program, Child Health Research Centre, The University of Queensland

Abdullah Al Tarique, Children's Health and Environment Program, Child Health Research Centre, The University of Queensland

Tamara Blake, Children's Health and Environment Program, Child Health Research Centre, The University of Queensland

Dwan Vilcins, Children's Health and Environment Program, Child Health Research Centre, The University of Queensland

Mohammad Zahirul Islam, Children's Health and Environment Program, Child Health Research Centre, The University of Queensland

Nazrul Islam, Faculty of Health, Queensland University of Technology

Robert S Ware, Menzies Health Institute Queensland, Griffith University

Peter Sly, Children's Health and Environment Program, Child Health Research Centre, The University of Queensland

\section{Funding sources}

Nil

\section{Conflicts of interest}

All authors declare they have no known conflicts of interest. 
medRxiv preprint doi: https://doi.org/10.1101/2022.01.03.22268699; this version posted January 5, 2022. The copyright holder for this preprint (which was not certified by peer review) is the author/funder, who has granted medRxiv a license to display the preprint in It is made available under a CC-BY 4.0 International license.

\section{Collaborators}

Nil

\section{Review question}

This review aims to explore whether the supplementation of vitamin D is effective in reducing respiratory tract infection and inflammation in patients with cystic fibrosis. We hypothesized that in cystic fibrosis patients who are supplemented with vitamin D, compared with placebo, there will be reduced bacterial infection.

P: Patients with cystic fibrosis

I: Vitamin D treatment/supplementation (any form of doses)

C: Control (placebo) is either no treatment or placebo treatment,

O: infection, inflammation and bacterial killing in the airway.

\section{Searches}

Multiple strategies will be used to identify studies published in English as of December 2021. Sources are four databases - PubMed, EMBASE via Elsevier, CINAHL via EBSCOhost and Web of Science (advanced), from inception to search date. Search strategies for each database were prepared by NB in consultation with other team members and a university library Information specialist. Preliminary searches were conducted using the various suggested terms to guide the study selection process.

\section{URL to search strategy}

The final search strategies as used in this systematic review are detailed in Appendix I.

\section{Condition or domain being studied}

Cystic fibrosis

\section{Participants/population}

Children or adult patients with cystic fibrosis will be included in the review. Detailed eligibility criteria are as follows:

The cystic fibrosis patients and

- vitamin D treatment - vitamin D2 or calciferol, vitamin D3, serum25(OH)D, cholecalciferol supplements with any form of doses such as cholecalciferol $1000 \mathrm{IU}$, ergocalciferol, vitamin complex such as vitamin ABDEK or multivitamin;

- infection and inflammation (sputum or blood microorganisms/pathogens) macrophage, neutrophil, Streptococci, Pseudomonas aeruginosa, interleukin-6 (IL-6), IL-8, IL-17, IL-23, LL-37, CRP, antimicrobial peptide, etc. 
medRxiv preprint doi: https://doi.org/10.1101/2022.01.03.22268699; this version posted January 5, 2022. The copyright holder for this preprint (which was not certified by peer review) is the author/funder, who has granted medRxiv a license to display the preprint in It is made available under a CC-BY 4.0 International license .

\section{Exclusion criteria}

Cystic fibrosis patients who underwent a lung transplant, UV light therapy for vitamin D will be excluded and no other restrictions will be applied based on comorbidities. Detailed exclusion criteria are as follows:

- No outcomes related to vitamin D treatment

- UV light therapy for vitamin D

- Not in a language that can be translated into English

- Full text not available/conference abstract/poster/meeting abstract/note

- Not original research/case study/review/book chapter/letter/review

- No comparator

- Conference proceedings/editorial/editorial material

- Duplicate study

\section{Intervention(s), exposure(s)}

Any form of vitamin D, say, vitamin D3 (known as cholecalciferol), vitamin D2 (ergocalciferol), etc. at any dose and any duration of intervention. Vitamin D treatment will help to inhibit inflammation and bacterial killing in the airway in cystic fibrosis.

\section{Comparator(s)/control}

Control (placebo) is either no treatment or placebo.

\section{Types of study to be included}

Randomised control trials (RCT) and quasi-randomised control trails such as single centre double-blinded cross-over RCT, multicentre double-blinded RCT, non-blinded RCT. All study designs other than randomized controlled trials (Cohort, Retrospective, case-control, case series, etc,) will be excluded in this review. Studies published as full-text articles that report original research will be eligible for inclusion.

\section{Context}

Studies in patients with cystic fibrosis and vitamin D treatment.

\section{Main outcome(s)}

The effectiveness of vitamin D helps in reducing respiratory tract infection and inflammation in cystic fibrosis patients. Vitamin D treatment will increase serum 25-hydroxyvitamin D (s25OHD), decrease plasma IL-8 or IL-23 concentration, which decreases neutrophil count to reduce inflammation in respiratory tract infection. Results from individual studies will be synthesized using random effect models depending on data quality and heterogeneity. For 
medRxiv preprint doi: https://doi.org/10.1101/2022.01.03.22268699; this version posted January 5, 2022. The copyright holder for this preprint (which was not certified by peer review) is the author/funder, who has granted medRxiv a license to display the preprint in perpetuity.
It is made available under a CC-BY 4.0 International license.

continuous outcomes mean differences (95\% confidence intervals) will be calculated, and for categorical outcomes odds ratios with $95 \%$ confidence intervals will be calculated to investigate the standardised mean difference (that is, measure of effect size) between the two groups.

\section{*Measure of effect:}

No restrictions on the outcome measure of vitamin D. Overall effects of vitamin D in terms of infection and inflammatory on blood or sputum inflammatory biomarkers. All outcomes will be collected at any time frame regardless study length and will analyse separately for shortterm (1-16 weeks) and medium term (16-52 weeks) outcomes to gather all possible evidence.

\section{Additional outcome(s):}

Identify the relationship between vitamin D status in CF and lung function outcomes defined by forced expiratory volume in 1 second $\left(\mathrm{FEV}_{1}\right)$, i.e., respiratory status - $\mathrm{FEV}_{1}$, other assessed respiratory parameters.

\section{Data extraction (selection and coding)}

The bibliographic software, EndNote, will be employed to organize, store, and manage all the references. References retrieved from all four databases will be imported into Endnote. After removal of duplicate references, studies will be selected by three reviewers based on predetermined study inclusion/exclusion criteria. The first selection will be based on title and abstract screening, and the second selection will be based on a full-text screening. Any conflict will be resolved by an independent reviewer. During the full-text screening, any exclusion reasons will be noted to be published in the supplementary material. Data extraction template will be created to gather study information. The template will contain information on author, year of publication, reference, the country in which the study conducted, study type and study design, no. of patients, patient's allocation, study length, baseline information on (age, s25OHD ( $\mathrm{ng} / \mathrm{ml}$ ), other descriptions including lung function - mean (standard deviation)), dose of vitamin D (IU) for intervention and comparator and list of outcomes. NB will extract data from each selected study. The overall quality of evidence for each outcome will assess according to the Grading of Recommendations Assessment, Development, and Evaluations (GRADE) guideline, which classify evidence as either very low, low, moderate, or high.

\section{Risk of bias (quality) assessment}

Two reviewers will perform the study quality assessment independently, with disagreements resolved by a third reviewer. Risk of bias will be assessed using RoB $2-$ A revised Cochrane risk-of-bias tool for randomised trials with adjustments made where necessary (15). 
medRxiv preprint doi: https://doi.org/10.1101/2022.01.03.22268699; this version posted January 5, 2022. The copyright holder for this preprint (which was not certified by peer review) is the author/funder, who has granted medRxiv a license to display the preprint in perpetuity.
It is made available under a CC-BY 4.0 International license.

\section{Strategy for data synthesis}

Studies included in this review will be grouped according to the primary and secondary outcomes as appropriate. When studies report sufficient data, a meta-analysis will be performed. Results from individual studies will be synthesized using random effect models depending on data quality and heterogeneity. For continuous outcomes mean differences $(95 \%$ confidence intervals) will be calculated, and for categorical outcomes odds ratios with $95 \%$ confidence intervals will be calculated to investigate the standardised mean difference (that is, measure of effect size) between the two groups. Heterogeneity will be measured using I-square statistic. A forest plot will be used to display the summary published findings/results for each study and the amount of study heterogeneity. Publication bias will be tested by generating funnel plots and applying Harbord's test (16). Analyses will be performed using Stata v17.0 (StataCorp LLC, College Station, TX, USA). The data synthesis will be performed by one reviewer, and the results will be checked by two other reviewers.

\section{Analysis of subgroups or subsets}

Nil

\section{Type and method of review}

Review type - Systematic review, meta-analysis

Health area of the review: Public health on cystic fibrosis

\section{Language}

English

\section{Country}

Australia

\section{Other registration details}

Nil

\section{Reference and/or URL for published protocol}

Protocol will be published on PROSPERO or medRxiv.

\section{Dissemination plans}

It is intended to publish the review article in a peer-reviewed journal. Any modifications to this proposal will be documented in the final published manuscript.

\section{Keywords}

Cystic Fibrosis, Vitamin D, infection, inflammation, antibacterial function 
medRxiv preprint doi: https://doi.org/10.1101/2022.01.03.22268699; this version posted January 5, 2022. The copyright holder for this preprint (which was not certified by peer review) is the author/funder, who has granted medRxiv a license to display the preprint in perpetuity.
It is made available under a CC-BY 4.0 International license.

37. Details of any existing review of the same topic by the same authors

Nil

\section{Current review status}

Ongoing

\section{Any additional information}

Nil

40. Details of final report/publication(s):

Subject index terms status

Subject indexing assigned by Centre for Reviews and Dissemination (CRD)

Subject index terms

Cystic Fibrosis, Antibacterial effects of vitamin D; Humans

\section{Reference}

1. Elborn JSP. Cystic fibrosis. Lancet. 2016;388(10059):2519-31.

2. Kanhere M, He J, Chassaing B, Ziegler TR, Alvarez JA, Ivie EA, et al. Bolus Weekly Vitamin D3 Supplementation Impacts Gut and Airway Microbiota in Adults With Cystic Fibrosis: A Double-Blind, Randomized, Placebo-Controlled Clinical Trial. The Journal of clinical endocrinology and metabolism. 2018;103(2):564-74.

3. Hall WB, Sparks AA, Aris RM. Vitamin d deficiency in cystic fibrosis. International journal of endocrinology. 2010;2010:218691.

4. Chesdachai S, Tangpricha V. Treatment of vitamin D deficiency in cystic fibrosis. J Steroid Biochem Mol Biol. 2016;164:36-9.

5. Stan IV, Bălănescu A, Codreanu IF, Belivaca AA, Ritivoiu ME, Drăgoi MM, et al. 25(OH) vitamin D deficiency in cystic fibrosis children - A prospective study on prevalence and treatment outcome. Farmacia (București). 2019;67(3):423-9.

6. Boyle MP, Noschese ML, Watts SL, Davis ME, Stenner SE, Lechtzin N. Failure of highdose ergocalciferol to correct vitamin D deficiency in adults with cystic fibrosis. American journal of respiratory and critical care medicine. 2005;172(2):212-7.

7. Rovner AJ, Stallings VA, Schall JI, Leonard MB, Zemel BS. Vitamin D insufficiency in children, adolescents, and young adults with cystic fibrosis despite routine oral supplementation. The American journal of clinical nutrition. 2007;86(6):1694-9. 
medRxiv preprint doi: https://doi.org/10.1101/2022.01.03.22268699; this version posted January 5, 2022. The copyright holder for this preprint (which was not certified by peer review) is the author/funder, who has granted medRxiv a license to display the preprint in perpetuity.
It is made available under a CC-BY 4.0 International license.

8. Tangpricha V, Kelly A, Stephenson A, Maguiness K, Enders J, Robinson KA, et al. An Update on the Screening, Diagnosis, Management, and Treatment of Vitamin D Deficiency in Individuals with Cystic Fibrosis: Evidence-Based Recommendations from the Cystic Fibrosis Foundation. The Journal of clinical endocrinology and metabolism. 2012;97(4):1082-93.

9. Dorlöchter L, Aksnes L, Fluge G. Faecal elastase-1 and fat-soluble vitamin profiles in patients with cystic fibrosis in Western Norway. Eur J Nutr. 2002;41(4):148-52.

10. Grossmann RE, Zughaier SM, Liu S, Lyles RH, Tangpricha V. Impact of vitamin D supplementation on markers of inflammation in adults with cystic fibrosis hospitalized for a pulmonary exacerbation. European journal of clinical nutrition. 2012;66(9):1072-4.

11. Pincikova T, Paquin-Proulx D, Sandberg JK, Flodström-Tullberg M, Hjelte L. Clinical impact of vitamin D treatment in cystic fibrosis: a pilot randomized, controlled trial. European journal of clinical nutrition. 2017;71(2):203-5.

12. Olszowiec-Chlebna M, Koniarek-Maniecka A, Brzozowska A, Błauż A, Rychlik B, Stelmach I. Vitamin D inhibits pro-inflammatory cytokines in the airways of cystic fibrosis patients infected by Pseudomonas aeruginosa- pilot study. Italian journal of pediatrics. 2019;45(1):41.

13. Moher D, Shamseer L, Clarke M, Ghersi D, Liberati A, Petticrew M, et al. Preferred reporting items for systematic review and meta-analysis protocols (PRISMA-P) 2015 statement. Syst Rev. 2015;4(1):1-.

14. Centre for Reviews and Dissemination. Guidance notes for registering a systematic review protocol with PROSPERO. York, UK: University of York [Internet]. 2016:[https://www.crd.york.ac.uk/prospero/documents/Registering\%20a\%review\%on\% PROSPERO.pdf. Accessed July 7, 2021 pp.].

15. Higgins JP, Altman DG, Gøtzsche PC, Jüni P, Moher D, Oxman AD, et al. The Cochrane Collaboration's tool for assessing risk of bias in randomised trials. Bmj. 2011;343:d5928.

16. Harbord RM, Egger M, Sterne JA. A modified test for small-study effects in meta-analyses of controlled trials with binary endpoints. Statistics in medicine. 2006;25(20):3443-57. 
medRxiv preprint doi: https://doi.org/10.1101/2022.01.03.22268699; this version posted January $5,2022$. The copyright holder for this preprint (which was not certified by peer review) is the author/funder, who has granted medRxiv a license to display the preprint in

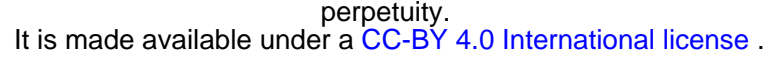

\section{Appendix I: Database Search Strategies}

PubMed

Search was performed on November 29, 2021 and returning 620 articles.

Query

("cystic fibrosis"[tiab] OR CF[tiab] OR "Cystic Fibrosis"[Mesh])

AND

("vitamin D"[tiab] OR D2[tiab] OR D3[tiab] OR "25-hydroxyvitamin D"[tiab] OR

cholecalciferol*[tiab] OR multivitamin*[tiab] OR supplementation[tiab] OR

supplement*[tiab] OR "Vitamin D"[Mesh])

AND

(Antibacterial[tiab] OR Anti-bacterial[tiab] OR antimicrobial[tiab] OR anti-microbial[tiab]

OR infection*[tiab] OR "respiratory infection*"[tiab] OR "respiratory bacteria"[tiab] OR inflammat*[tiab] OR pro-inflammat*[tiab] OR CRP[tiab] OR "c-reactive protein"[tiab] OR phagocytosis[tiab] OR macrophage*[tiab] OR neutrophil*[tiab] OR NE[tiab] OR streptococc*[tiab] OR "airway surface liquid"[tiab] OR ASL[tiab] OR "Pseudomonas aeruginosa"[tiab] OR "antimicrobial peptide"[tiab] OR IL[tiab] OR interleukin*[tiab] OR IL6[tiab] OR IL-8[tiab] OR IL-17[tiab] OR IL-23[tiab] OR LL-37[tiab] OR cytokin*[tiab] OR microbiota[tiab] OR microbiome[tiab] OR "Anti-Infective Agents"[Mesh] OR "Inflammation"[Mesh] OR "Infections"[Mesh])

\section{EMBASE (via Elsevier)}

Search was performed on November 29, 2021 and returning 2,010 articles.

\section{Query}

("cystic fibrosis":ti,ab OR CF:ti,ab OR "Cystic Fibrosis"/exp)

AND

("vitamin D":ti,ab OR D2:ti,ab OR D3:ti,ab OR "25-hydroxyvitamin D":ti,ab OR

cholecalciferol*:ti,ab OR multivitamin*:ti,ab OR supplementation:ti,ab OR supplement*:ti,ab OR "Vitamin D"/exp)

AND

(Antibacterial:ti,ab OR Anti-bacterial:ti,ab OR antimicrobial:ti,ab OR anti-microbial:ti,ab OR infection*:ti,ab OR "respiratory infection*":ti,ab OR "respiratory bacteria":ti,ab OR inflammat*:ti,ab OR pro-inflammat*:ti,ab OR CRP:ti,ab OR "c-reactive protein":ti,ab OR phagocytosis:ti,ab OR macrophage*:ti,ab OR neutrophil*:ti,ab OR NE:ti,ab OR streptococc*:ti,ab OR "airway surface liquid":ti,ab OR ASL:ti,ab OR "Pseudomonas aeruginosa":ti,ab OR "antimicrobial peptide":ti,ab OR IL:ti,ab OR interleukin*:ti,ab OR IL6:ti,ab OR IL-8:ti,ab OR IL-17:ti,ab OR IL-23:ti,ab OR LL-37:ti,ab OR cytokin*:ti,ab OR microbiota:ti,ab OR microbiome:ti,ab OR "AntiInfective Agent"/exp OR Inflammation/exp OR Infection/exp)

AND

[embase]/lim

\section{CINAHL (via EBSCOhost)}

Search was performed on November 29, 2021 and returning 121 articles.

Query 
medRxiv preprint doi: https://doi.org/10.1101/2022.01.03.22268699; this version posted January 5, 2022. The copyright holder for this preprint (which was not certified by peer review) is the author/funder, who has granted medRxiv a license to display the preprint in

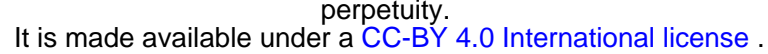

((TI "cystic fibrosis" OR AB "cystic fibrosis") OR (TI "CF" OR AB "CF") OR (MH "Cystic Fibrosis"+))

AND

((TI "vitamin D" OR AB "vitamin

D") OR (TI D2 OR AB D2) OR (TI D3 OR AB D3) OR (TI "25-hydroxyvitamin

D" OR AB "25-hydroxyvitamin

D") OR (TI cholecalciferol* OR AB cholecalciferol*) OR (TI multivitamin* OR AB multivit amin*) OR (TI supplementation OR AB supplementation) OR (TI supplement* OR AB suppl ement*) OR (MH "Vitamin D"+))

AND

((TI Antibacterial OR AB Antibacterial) OR (TI Anti-bacterial OR AB Anti-

bacterial) OR (TI antimicrobial OR AB antimicrobial) OR (TI anti-microbial OR AB anti-

microbial) OR (TI infection* OR AB infection*) OR (TI "respiratory

infection*" OR AB "respiratory infection*") OR (TI "respiratory

bacteria" OR AB "respiratory bacteria") OR (TI inflammat* OR AB inflammat*) OR (TI proinflammat* OR AB pro-inflammat*) OR (TI CRP OR AB CRP) OR (TI "c-reactive

protein" OR AB "c-reactive

protein") OR (TI phagocytosis OR AB phagocytosis) OR (TI macrophage* OR AB macropha ge*) OR (TI neutrophil* OR AB neutrophil*) OR (TI NE OR AB NE) OR (TI streptococc*

OR AB streptococc*) OR (TI "airway surface liquid" OR AB "airway surface

liquid") OR (TI ASL OR AB ASL) OR (TI "Pseudomonas

aeruginosa" OR AB "Pseudomonas aeruginosa") OR (TI "antimicrobial

peptide" OR AB "antimicrobial

peptide") OR (TI IL* OR AB IL*) OR (TI interleukin* OR AB interleukin*) OR (TI IL-

6 OR AB IL-6) OR (TI IL-8 OR AB IL-8) OR (TI IL-17 OR AB IL-17) OR (TI IL-

23 OR AB IL-23) OR (TI LL-37 OR AB LL-

37) OR (TI cytokin* OR AB cytokin*) OR (TI microbiota OR AB microbiota) OR (TI micro biome OR AB microbiome) OR (MH "Antiinfective

Agent"+) OR (MH Inflammation+) OR (MH Infection+))

\section{Web of Science (advanced)}

Search was performed on November 29, 2021 and returning 751 articles.

\section{Query}

((TI="cystic fibrosis" OR AB="cystic fibrosis") OR (TI=CF OR AB=CF) OR ALL="Cystic Fibrosis")

AND

((TI="vitamin D" OR AB="vitamin

D") OR (TI=D2 OR AB=D2) OR (TI=D3 OR AB=D3) OR (TI="25-hydroxyvitamin

D" OR AB="25-hydroxyvitamin

D") OR (TI=cholecalciferol* OR AB=cholecalciferol*) OR (TI=multivitamin* OR AB=multi vitamin*) $\mathrm{OR}$ (TI=supplementation $\mathrm{OR} A B=$ supplementation) $\mathrm{OR}$ (TI=supplement* $\mathrm{OR} \mathrm{AB}$ =supplement*) OR ALL="Vitamin D")

AND

( $(\mathrm{TI}=$ Antibacterial $\mathrm{OR} \mathrm{AB}=$ Antibacterial $) \mathrm{OR}(\mathrm{TI}=$ Anti-bacterial OR AB=Anti-

bacterial) $\mathrm{OR}(\mathrm{TI}=$ antimicrobial $\mathrm{OR} \mathrm{AB}=$ antimicrobial $) \mathrm{OR}(\mathrm{TI}=$ anti-microbial $\mathrm{OR} \mathrm{AB}=$ antimicrobial) OR (TI=infection* OR AB=infection*) OR (TI="respiratory

infection*" OR $\mathrm{AB}=$ "respiratory infection*") $\mathrm{OR}(\mathrm{TI}=$ "respiratory

bacteria" OR AB="respiratory

bacteria") OR (TI=inflammat* OR AB=inflammat*) OR (TI=pro-inflammat* OR AB=pro- 
medRxiv preprint doi: https://doi.org/10.1101/2022.01.03.22268699; this version posted January 5, 2022. The copyright holder for this preprint (which was not certified by peer review) is the author/funder, who has granted medRxiv a license to display the preprint in perpetuity.

It is made available under a CC-BY 4.0 International license .

inflammat*) OR (TI=CRP OR AB=CRP) OR (TI="c-reactive protein" OR AB="c-reactive protein") $\mathrm{OR}$ ( $\mathrm{TI}=$ phagocytosis $\mathrm{OR} \mathrm{AB}=$ phagocytosis) $\mathrm{OR}$ (TI=macrophage* $\mathrm{OR} \mathrm{AB}=$ macro phage*) OR (TI=neutrophil* OR AB=neutrophil*) OR (TI=NE OR AB=NE) OR (TI=strepto cocc* $\mathrm{OR} A B=$ streptococc*) $\mathrm{OR}(\mathrm{TI}=$ "airway surface liquid" $\mathrm{OR} \mathrm{AB}=$ "airway surface liquid") OR (TI=ASL OR AB=ASL) OR (TI="Pseudomonas aeruginosa" OR $\mathrm{AB}=$ =Pseudomonas aeruginosa") $\mathrm{OR}(\mathrm{TI}=$ "antimicrobial peptide" OR AB="antimicrobial

peptide") OR (TI=IL OR AB=IL) OR (TI=interleukin* OR AB=interleukin*) OR (TI=IL6 OR AB=IL-6) OR (TI=IL-8 OR AB=IL-8) OR (TI=IL-17 OR AB=IL-17) OR (TI=IL23 OR AB=IL-23) OR (TI=LL-37 OR AB=LL-

37) $\mathrm{OR}(\mathrm{TI}=$ cytokin* $\mathrm{OR} \mathrm{AB}=$ cytokin*) $\mathrm{OR}(\mathrm{TI}=$ microbiota $\mathrm{OR} \mathrm{AB}=$ microbiota $) \mathrm{OR}(\mathrm{TI}=\mathrm{mi}$ crobiome $\mathrm{OR} A B=$ microbiome) $\mathrm{OR}$ ALL="Anti-Infective

Agents" OR ALL=Inflammation OR ALL=Infections) 